\title{
From Buried Dead to Alive in Your Pocket: Moving Fossil Data from Spreadsheet to Database to Print to Mobile Phone Key APP
}

Finnegan Marsh ${ }^{1} \&$ Conrad Labandeira ${ }^{1-3}$

Tracing the path of arthropods-flora interactions from their millions-old deposition \& burial toward a live user-responsive interaction smartphone application.

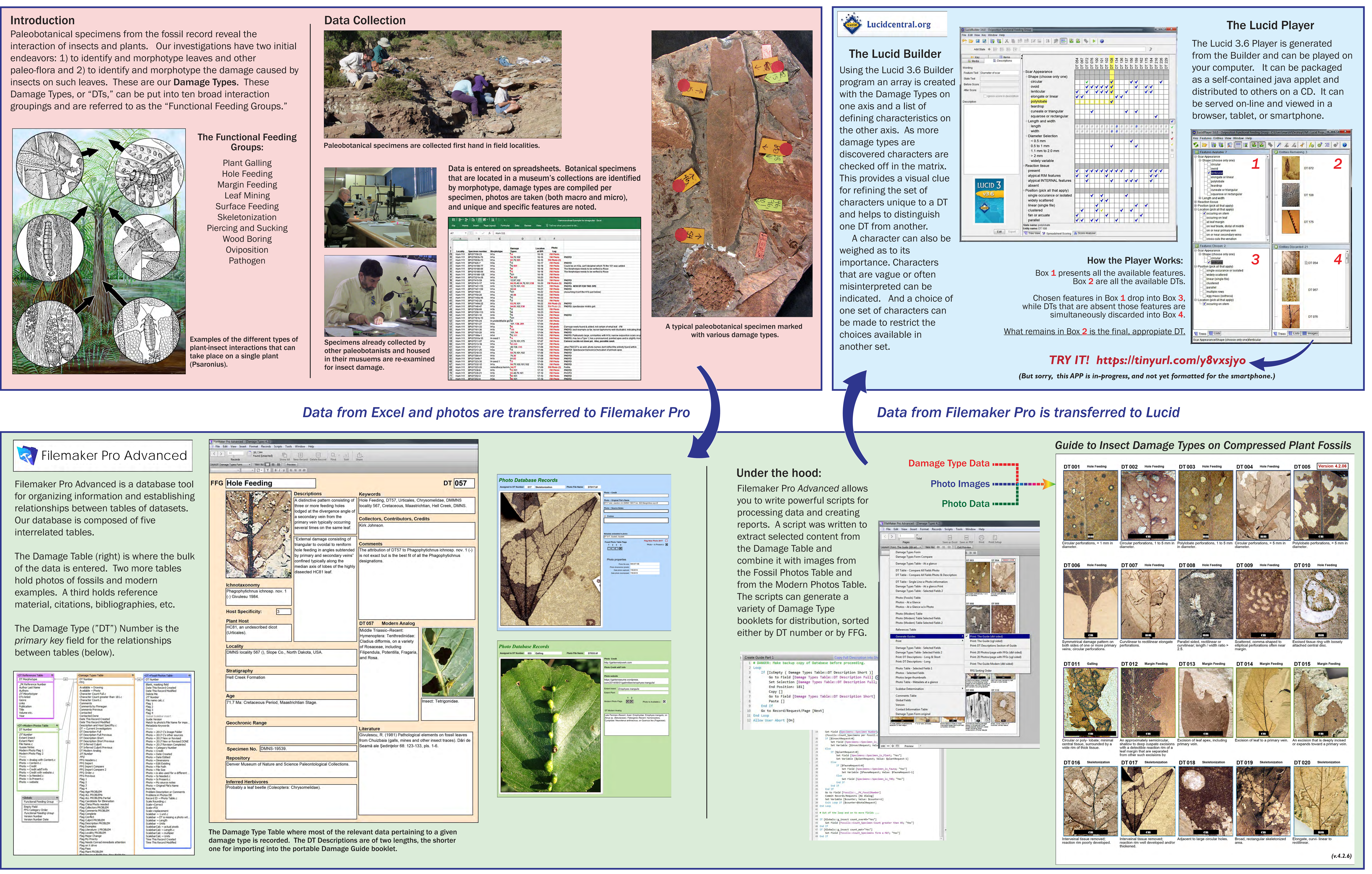

